\title{
CONCEPTUALIZATION OF PROSPECTIVE TRAJECTORIES FOR FARMING DEVELOPMENT IN CONDITIONS OF MODERN CHALLENGES AND THREATS ${ }^{1}$
}

\author{
Svetlana G. Golovina \\ Ural State Agrarian University, Yekaterinburg, Russian Federation \\ Ekaterina V. Abilova \\ Chelyabinsk State University, Chelyabinsk, Russian Federation
}

\begin{abstract}
In the modern socio-economic, political and institutional environment, in the face of new global challenges and threats (sanctions restrictions, natural disasters, epidemics and pandemics), which determine high economic and social instability, farmers are gaining special importance in the Russian agricultural economy development because of their inextricable links with rural communities and close incorporating into rural areas. In the presented article, a farm is identified not only as an efficiently functioning business unit, but also as a socially responsible organizational artifact that acts as a guarantor and driver of sustainable development of rural areas in times of significant fluctuations of the environment. The theoretical novelty of the scientific results lies in the complexity and interdisciplinarity of the conceptual approach to their obtaining, based on the multifunctionality of the studied phenomenon. The applied significance is in the expediency of their use both in the strategic work of the authorities (implementing programs for supporting farming to perform socially significant functions) and in the organization of the activities of farmers themselves in order to increase sustainability of their life (by expanding the performed functions) and the growth of their public image (through integration into rural societies).

Key words: development concept, peasant farm enterprise, socio-economic environment, global challenges, external and internal threats, multifunctionality, organizational and technological features, development trajectory.

Citation. Golovina S.G., Abilova E.V. Conceptualization of Prospective Trajectories for Farming Development in Conditions of Modern Challenges and Threats. Vestnik Volgogradskogo gosudarstvennogo universiteta. Ekonomika [Journal of Volgograd State University. Economics], 2021, vol. 23, no. 1, pp. 153-167. (in Russian). DOI: https://doi.org/10.15688/ek.jvolsu.2021.1.13
\end{abstract}

\section{КОНЦЕПТУАЛИЗАЦИЯ ПЕРСПЕКТИВНЫХ ТРАЕКТОРИЙ РАЗВИТИЯ ФЕРМЕРСТВА В УСЛОВИЯХ СОВРЕМЕННЫХ ВЫЗОВОВ И УГРОЗ ${ }^{1}$}

\author{
Светлана Георгиевна Головина \\ Уральский государственный аграрный университет, г. Екатеринбург, Российская Федерация \\ Екатерина Викторовна Абилова \\ Челябинский государственный университет, г. Челябинск, Российская Федерация
}

Аннотация. В современной социально-экономической, политической и институциональной среде в условиях новых глобальных вызовов и угроз (санкционные ограничения, природные катаклизмы, эпидемии 
и пандемии), детерминирующих высокую экономическую и социальную нестабильность, особую значимость в развитии отечественной аграрной экономики представляют крестьянские (фермерские) хозяйства, жизнедеятельность которых неразрывно связана с сельскими сообществами и тесно инкорпорирована в сельские территории. В представленной статье крестьянское (фермерское) хозяйство идентифицируется не только в качестве эффективно функционирующей бизнес-единицы, но и одновременно в роли социально ответственного организационного артефакта, выступающего гарантом и драйвером устойчивого развития сельских территорий во времена существенных (и заранее непредсказуемых) флуктуаций среды. Теоретическая новизна научных результатов заключается в комплексности и междисциплинарности концептуального подхода к их получению, основанного на многофункциональности исследуемого феномена, прикладная значимость - в целесообразности их использования как в стратегической работе органов власти по реализации программ поддержки фермерства для выполнения им общественно значимых функций, так и в организации деятельности самих крестьянских (фермерских) хозяйств в целях повышения устойчивости их жизнедеятельности (за счет расширения выполняемых функций) и роста общественного имиджа (посредством тесной интеграции в сельский социум).

Ключевые слова: концепция развития, крестьянские (фермерские) хозяйства, социально-экономическая среда, глобальные вызовы, внешние и внутренние угрозы, многофункциональность, организационнотехнологические особенности, траектория развития.

Цитирование. Головина С. Г., Абилова Е. В. Концептуализация перспективных траекторий развития фермерства в условиях современных вызовов и угроз // Вестник Волгоградского государственного университета. Экономика. - 2021. - Т. 23, № 1. - С. 153-167. - DOI: https://doi.org/10.15688/ek.jvolsu.2021.1.13

\section{Введение}

Создание условий для эффективного функционирования крестьянских (фермерских) хозяйств, обладающих достаточной конкурентоспособностью и выполняющих важнейшие задачи по развитию сельскохозяйственного производства, сельских территорий и сельских сообществ, является актуальной проблемой для аграрных регионов Российской Федерации, получивших новые возможности, на фоне повышения значимости аграрной отрасли экономики в обеспечении экономической (продовольственной) безопасности страны, введения экономических санкций, формирования негативных последствий пандемии COVID-19 для аграрной отрасли и сельского населения, высокой вероятности возникновения других серьезных угроз политического, экологического, биологического (и другого) характера. Не случайно в приветствии делегатов и участников XXVIII Съезда АККОР (2018 г.) Президент России В.В. Путин отметил, что «за короткий по историческим меркам срок российское фермерство убедительно доказало свою экономическую и социальную значимость, стало серьезной созидательной силой, достойно продолжило лучшие традиции крестьянского труда, которыми всегда славилась наша страна» [Путин ... XXVIII Съезд], а в обращении к участникам
XXXI Съезда АККОР (2020 г.) акцентировал внимание на том, что «год от года фермерство укрепляет свою роль в реализации потенциала отечественного агропромышленного комплекса, повышении качества жизни на селе, напрямую влияя на развитие регионов и национальной экономики в целом» [Путин ... XXXI Съезд].

В свою очередь, главы российских регионов, в том числе областей Уральского федерального округа (далее - УФО), также высоко оценивают значимость для развития сельскохозяйственной отрасли и сельских территорий такой формы организации аграрной деятельности, как крестьянское (фермерское) хозяйство, поддерживая особое отношение к фермерству со стороны государственных структур, приветствуя оказание фермерам всесторонней и существенной помощи, лоббируя их интересы.

В русле такого внимания южноуральским фермерам (Челябинская область), к примеру, в рамках национального проекта «Малое и среднее предпринимательство» в 2019 г. выделено грантов на сумму около 200 млн руб., из них 105 млн руб. направлено 25 начинающим фермерам, 60 млн руб. - фермерам, участвующим в различных стартапах в аграрном секторе, 30 млн руб. - трем семейным фермам. В 2020 г. на поддержку семейных ферм и новых фермерских хозяйств (в частности, 
трех семейных фермерских хозяйств и 22 начинающих фермеров) выделено 120 млн руб. (меньше относительно предыдущего года в связи со сложной экономической ситуацией в стране) [Региональный проект ...].

В Курганской же области поддержка малого аграрного бизнеса осуществляется согласно мероприятиям государственной областной программы «Развитие агропромышленного комплекса в Курганской области», в результате чего в 2020 г. семейным фермам предоставлено 11 грантов, начинающим фермерам - 32 гранта, сельскохозяйственным потребительским кооперативам 3 гранта, участникам программы «Агростартап» - 6 грантов. В итоге, на поддержку малых форм хозяйствования в качестве грантов направлено 458,9 млн руб. или в 2,1 раза больше по сравнению с 2019 г. [Поддержка фермерства ...].

Заинтересованность общества и государства в успешной деятельности фермеров тесно коррелирует с активизацией политики импортозамещения и, безусловно, с вызовами, связанными с различными техногенными, политическими и другими флуктуациями (подобными пандемии коронавируса или беспрецедентным экономическим санкциям). В отмеченных условиях основные исследовательские задачи аграрной экономической науки сводятся к изучению таких аспектов развития фермерства, как: 1) влияние внешней среды (институциональной, рыночной, макроэкономической, глобальной) на развитие крестьянских (фермерских) хозяйств; 2) их новая роль в сельском развитии; 3) содержание среднесрочных и долгосрочных прогнозов функционирования крестьянских (фермерских) хозяйств; 4) оптимальные направления и инструменты государственной поддержки фермерства, подходы к оценке их эффективности.

С учетом динамичной и комплексной природы происходящих вокруг фермерства изменений [Гайсин, 2016] и сам изучаемый феномен [крестьянское (фермерское) хозяйство] требует нового подхода к исследованию его внутреннего (все усложняющегося) устройства, особенностей совершаемых им трансакций (с поставщиками ресурсов, переработчиками аграрного сырья, производителями продуктов питания, политическими и социальными институтами), альтернативных организационных моделей функционирования фермерских хозяйств, модифицирующихся на фоне происходящих на аграрных рынках сложных и интерактивных процессов. Следствием перечисленных обстоятельств для данной работы является то, что спектр обозначенных научных интересов мотивировал использование в ходе определения перспективных траекторий развития российского фермерства (в мобильной институциональной среде в условиях высокой неопределенности и рисков) нового (междисциплинарного, комплексного) подхода.

\section{Подходы и методы}

С точки зрения методологии перспективные траектории развития фермерства в отмеченных условиях среды целесообразно определять на основе учета как специфики изучаемого объекта и его современного состояния, так и динамики условий, в которых он развивается. Особенно это актуально для данной формы хозяйствования [крестьянское (фермерское) хозяйство], функционирование которой, с одной стороны, непосредственно связано с уникальностью отрасли (сельское хозяйство), существенно зависящей от природно-климатических факторов, практически не поддающихся контролю и часто меняющихся в неблагоприятную сторону, но с другой детерминируется новыми стимулами, сопряженными с ростом спроса на сельскохозяйственное сырье и продовольствие, глобальными технологическими усовершенствованиями, инновациями не только в технологических процессах, но и организационных аспектах деятельности аграрных хозяйств.

Несмотря на то что проблемам фермерства в современной экономической науке уделяется большое внимание, многие вопросы относительно его развития в условиях глобализации, стремительного технического прогресса, урбанизации (и других современных явлений) остаются все же нерешенными. Следовательно, обновленный концептуальный подход к формированию и развитию фермерства способен обеспечить теоретическую базу для успешного развития сельского хозяйства в условиях сложившихся институциональных ог- 
раничений, мобильности внутренней и внешней среды, высокой социально-экономической неопределенности и новых угроз политического и биологического характера. По сути, важным теоретическим основанием определения путей формирования успешно функционирующих фермерских хозяйств является концептуальный постулат, содержание которого заключается в том, что с позиции государства и общества результативность работы фермеров сводится не только к сугубо экономической эффективности, но и к разнообразным социальным и экологическим экстерналиям.

В связи с этим научной базой реализации заявленной в работе цели (определение перспективных траекторий развития фермерства) являются современные научные доктрины, интегрирующие наиболее актуальные достижения различных дисциплин в изучении поведения объектов в сложной флуктуирующей среде, а предложенный методологический подход к развитию фермерских хозяйств базируется на таких аспектах, как, во-первых, многофункциональность их деятельности в границах сельских территорий, во-вторых, еe пространственная локализация и социальная аффилированность, в-третьих, организационно-технологические особенности функционирования фермерских хозяйств.

Так, на основе изучения и обобщения достижений применяемой в современной экономической науке доктрины многофункциональности (в совокупности с территориальными особенностями фермерской деятельности, ее непосредственной причастностью к сельским территориям и сельскому социуму) признается особый вклад крестьянских (фермерских) хозяйств в реализацию социальных и экологических (помимо экономических) целей развития сельских территорий и сельских сообществ. Данные вопросы исследования (многофункциональность, локальность, встроенность в сельские сообщества) идентифицируются как важные элементы комплексной (и продуктивной) методологии изучения тенденций развития фермерства в стране и отдельных ее регионах, а также трендов развития фермерства в целом.

Кроме того, технологические особенности фермерских хозяйств (еще один элемент предлагаемой концепции) обусловливают в конкретном территориальном пространстве (в данном исследовании в регионах УФО) прежде всего спецификацию оптимальных возможностей (условий) деятельности крестьянских (фермерских) хозяйств с учетом как возникающих в процессе фермерской деятельности сложностей, так и благоприятствующих развитию фермерства обстоятельств, касающихся совершенно конкретных видов аграрного производства (животноводства, растениеводства и др.).

\section{Результаты}

На основании базовых элементов обозначенного выше комплексного научного подхода к исследованию фермерства в сложившихся условиях (многофункциональная природа объекта и его общественная значимость; специализация деятельности; уникальность траекторий создания; особенности происходящих, в том числе глобальных, изменений) для определения перспективных траекторий развития фермерских хозяйств в первую очередь изучению подлежит их многофункциональность, предполагающая (помимо производства сельскохозяйственной продукции) такие виды деятельности, как переработка сельскохозяйственного сырья, производство продуктов питания, их реализация. Более того, расширению бизнес-возможностей фермеров и повышению их доходов способствует организация логистики, сосредоточение на биодинамическом и органическом производстве, развитие агротуризма и других (способствующих сохранению сельских территорий) видов активности. Как показывают аналитические материалы, именно диверсификация активов (и как следствие доходов) является в сложившейся современной среде действенной стратегией, способной, в отличие от простого увеличения размеров хозяйств, модернизировать фермерское производство и обеспечить (путем многофункциональности деятельности): 1) значительный рост эффективности функционирования хозяйственных единиц; 2) повышение их конкурентоспособности [Кравченко и др., 2018].

Подчеркнем, что, по мнению, например, западных ученых, разнообразиепроизводимой крестьянскими (фермерскими) хозяйствами продукции и широкий спектр предоставляе- 
мых ими услуг (включая, безусловно, природоохранные и социально-культурные) позволяют выделить (в зависимости от вида деятельности) несколько конкретных выполняемых ими функций:

1) производственная, имеются в виду любые операции, связанные с производством сельскохозяйственного сырья, его переработкой в продукты питания и другую продукцию, а также деятельность по предоставлению туристических и других услуг;

2) соииальная, означающая решение фермерскими хозяйствами многих социальных задач (содействие образовательным, медицинским, культурным, рекреационным мероприятиям на селе; расширение занятости населения; культивирование национальных традиций; создание условий для формирования актуальной в сегодняшней ситуации социальной сплоченности (социальных сетей);

3) экологическая, характеризующаяся в первую очередь организацией действенных мероприятий по защите биоразнообразия, предотвращению загрязнения окружающей среды, воспроизводству природных ресурсов [Easley et al., 2000].

В целом же анализ научных источников позволяет сделать несколько существенных выводов. Во-первых, для сельского сообщества (в том числе фермеров) вполне очевидна связь многофункциональности сельского хозяйства и устойчивости крестьянских (фермерских) хозяйств, что (на практике) мотивирует их глав к постановке (в соответствии с выбранной траекторией развития) и достижению долгосрочных экономических, социальных, экологических целей [Unay et al., 2019].

Во-вторых, в исследованиях верифицирована гипотеза о том, что поддержание фермерами многофункциональности деятельности детерминирует лучшую выживаемость крестьянских (фермерских) хозяйств в экстраординарных условиях, требуемую временем эффективность производства, динамичное и перманентное развитие [O фермерстве ..., 2019].

В-третьих, очевидна корреляция между такими реалиями, как многофункциональность, локальная принадлежность, территориальный ресурсный потенциал, доказывающая, что на успешность многофункциональной фермерской деятельности существенное влияние оказывают характеристики территории ее осуществления, включая ресурсные возможности [Cairol et al., 2009].

Кроме того, как показывает опыт, в укреплении социальной сплоченности, улучшении и сохранении экологической системы, оказании значимого влияния на общее благосостояние региона (его конкурентоспособность) сельскохозяйственные организации отмечаются успехами в том случае, когда тесно связаны с местным сообществом, глубоко интегрированы в локальную экономику, нацелены в своей деятельности на общественно значимые (формулируемые в рамках сельских территорий) экономические и социальные результаты.

Обращаясь к идее многофункциональности, важно рассмотреть возможность ее использования в оценке эффективности деятельности крестьянских (фермерских) хозяйств, учитывая как сугубо производственный аспект их функционирования, так и, конечно же, социальный и экологический. При этом (согласно результатам аналитического обзора научных работ) следует отметить, что в достижении адекватных показателей эффективности исследователи отмечают и обосновывают высокую значимость не только многофункциональности фермерской деятельности, но и ее территориального контекста [Cairol et al., 2009].

В частности, как утверждают Д. Кэйрол и его коллеги, данная ситуация объясняется тем, что выполняемые фермерскими хозяйствами функции: 1) касаются большинства звеньев технологической цепи, распространяясь, по сути, далеко за пределы основной деятельности; 2) проникают в различные (несельскохозяйственные) экономические сегменты, а мультифункциональный подход (дополненный учетом территориальных аспектов) охватывает социальную, экологическую результативность функционирования аграрных организаций, оцениваемую в границах определенных сельских территорий как значимую даже по сравнению с результативностью экономической [Knickel et al., 2000].

Немаловажно, что социально ориентированная и территориально встроенная модель аграрной бизнес-единицы (ассоциируемая 
главным образом с семейным фермерским хозяйством) противопоставляется учеными (представителями территориального подхода) традиционным моделям, в основе которых рост капиталоемкости производства и технологические инновации, идентифицируемые в качестве условия успешного развития сельского хозяйства [Knickel et al., 2013].

В итоге, результаты предыдущих исследований однозначно указывают на тесные синергетические связи между деятельностью уникальных по природе (фермерских) хозяйств и устойчивостью развития сельских территорий [Головина и др., 2016]. В том числе в них теоретически и эмпирически аргументируется, что крестьянские (фермерские) хозяйства как крупные пользователи земельных и других ресурсов играют важную роль в трудоустройстве селян, получении ими доходов, культивировании национальных традиций, стимулируя, таким образом, успешное развитие сельских территорий, решая проблемы экологии, обеспечивая достойные условия жизни сельскому населению.

Применительно к данному исследованию (с целью решения задач его эмпирической части), на основании имеющихся в теории и применяемых на практике подходов к многофункциональности (социальной встроенности, территориальной причастности), все функции фермерских хозяйств целесообразно представить в виде двух уровней, в основе первого из которых - производство сельскохозяйственного сырья и продуктов питания (основная функция), а второго - вторичные функции, связанные с различными аспектами устойчивого развития сельских территорий и сельских сообществ, а именно с решением социальных, экологических, а также экономических (дополнительных) задач. По сути, выполнение крестьянскими (фермерскими) хозяйствами всех обозначенных функций (как основной, так и вторичных) обусловливает успешное развитие того или иного региона (см. рисунок).

Уместно отметить, что в построении оптимальных трендов развития фермерства концепция многофункциональности (вторичные функции выполняются одновременно с основной функцией) обладает высоким эвристическим потенциалом непосредственно в совокупности с территориальным подходом, так как осуществляемые фермерами функции, во-первых, получают реальную оценку, специфичную для конкретного региона (оцениваются в зависимости от сформулированных в границах той или иной локальности целей, достигнутого уровня социально-экономического развития); во-вторых, дифференцируются по

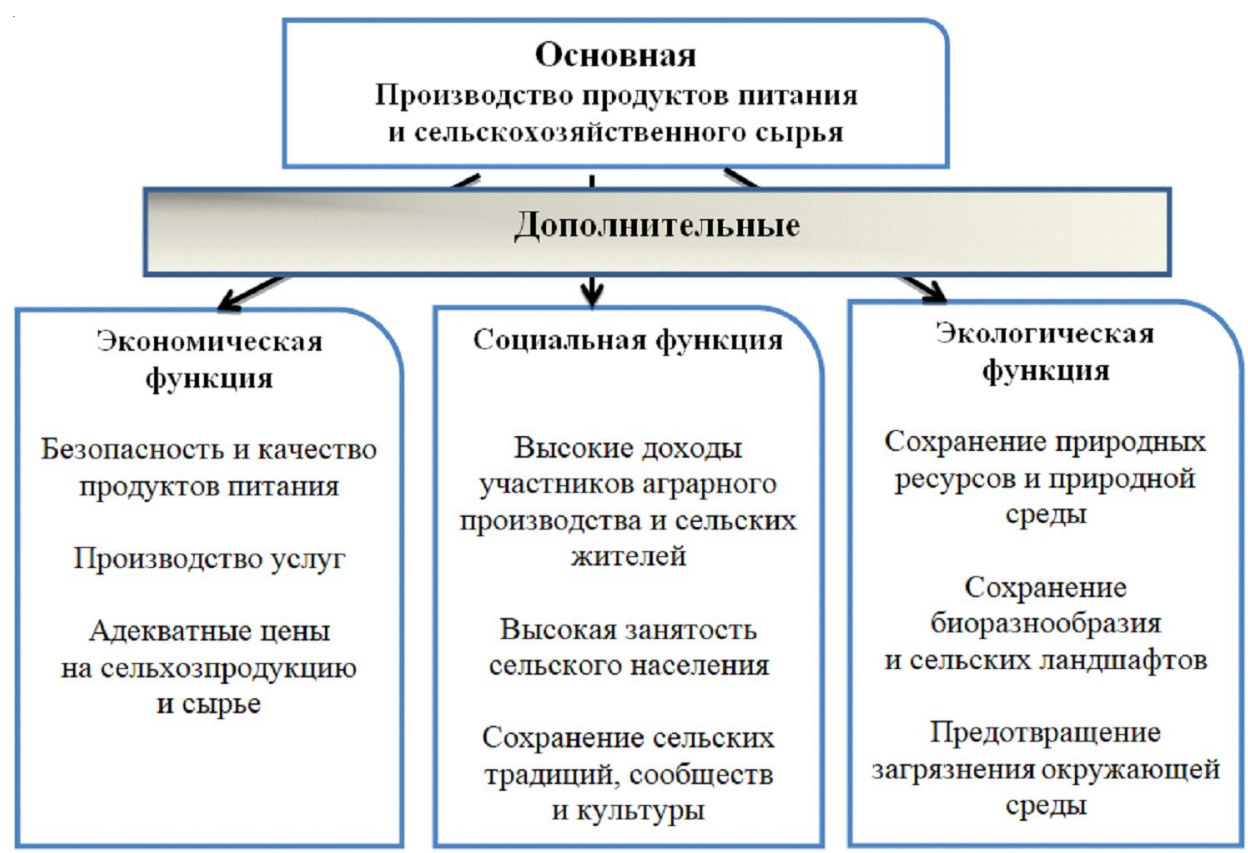

Рисунок. Иерархическая схема выполняемых крестьянскими (фермерскими) хозяйствами функций Примечание. Составлено авторами. 
значимости от территории к территории (если в одних областях большое значение придается именно производству и экономическим функциям, то в других - экологии, социальным функциям, рекреации).

Как итог, чтобы правильно определить общественные приоритеты, используя полученные результаты в построении прогнозов (в том числе относительно траекторий развития фермерства), перед представителями государственных органов и учеными возникают вопросы относительно спецификации общественно значимых направлений фермерской деятельности и измерения имеющегося (с позиции выделенного спектра ценностей) потенциала. Безусловно, эти оценки важны и необходимы, так как информируют о готовности потребителей получать (оплачивать) те блага и услуги аграрного производства, которые можно определить как «нерыночные».

Эмпирическая часть исследования (исходя из поставленных задач) реализована на материалах Курганской области (традиционного аграрного региона УФО), при этом практическая ее направленность характеризуется:

1) формированием особого концептуального подхода, доказывающего важность общественных преференций в идентификации перспективных траекторий развития фермерских хозяйств;

2) разработкой приемлемой (для российских регионов в целом) методики оценки этих преференций.

Следует отметить, что наиболее целесообразным методом выявления социальных потребностей жителей сельских территорий в нерыночных следствиях деятельности аграрных организаций является метод условной оценки (CV - Contingent Valuation), базирующийся на результатах опроса селян, в частности, о том, как действительно они оценивают (на данный момент) получение конкретного блага (например, безопасное и качественное питание, чистая экология, удовлетворение тех или иных социальных потребностей и т. д.) [Kallas et al., 2007]. Благодаря этому методу стала возможна комплексная оценка важности для большинства сельских жителей региона (Курганской области) выделенных в деятельности крестьянских (фермерских) хо- зяйств экономических, социальных, экологических функций.

В ходе реализации экспериментальной части исследования был организован опрос (анкетирование, интервьюирование) широкого круга респондентов (всего 1829 представителей сельских сообществ различного пола и возраста), в числе которых главы и члены крестьянских (фермерских) хозяйств, работники сельскохозяйственных организаций, сельские жители (ведущие личное подсобное хозяйство), поставщики тех или иных услуг для сельского населения, пенсионеры. Сопоставление респондентами ценности одной альтернативы по сравнению с другой реализовано посредством представления вопросов в анкете в виде парных сравнений.

Причем если первый этап опроса означал выбор предпочтений между такими функциями деятельности крестьянских (фермерских) хозяйств, как экономическая, социальная, экологическая (в целом), то на следующем (втором) этапе респонденты оценивали по шкале Саати (опять же путем сравнений) непосредственные (конкретные) результаты обозначенных функций (как известно, для проведения сравнений Т. Саати предложил использовать в ответах шкалу от 1 до 9 [Saaty, 1980]).

В итоге, посредством данного метода (рассчитанных совокупных весов) выявлены предпочитаемые селянами те или иные аспекты деятельности аграрных хозяйств (с агрегированием результатов как по отдельным районам, так и по Курганской области в целом).

В результате проведенных расчетов была выявлена тесная связь между экономическим, социальным и экологическим развитием сельских территорий исследуемого субъекта (Курганской области). Так, в районах области, в которых населением высоко ценится состояние непосредственно социальной сферы и окружающей среды (как правило, здесь успешно решаются основные экономические задачи, фиксируются относительно высокие показатели уровня жизни селян), в качестве наиболее значимых отмечаются не только экономические функции фермерства, но и социальные, экологические, причем в неменьшей степени. Однако по Курганской об- 
ласти в целом жители сельских территорий (из-за сложной экономической ситуации) более приоритетной считают все же экономическую функцию аграрных хозяйств, значимо дистанцируя от нее социальную и экологическую функции (вес экономической функции крестьянских (фермерских) хозяйств составляет $52,4 \%$, социальной - $32,2 \%$, экологической 15,4 \%). Причем, формулируя экономические, социальные и экологические проблемы развития соответствующих территорий, сельское население (как следует из опроса) предписывает особую роль в их решении не инвесторо-ориентированным предприятиям, интересы которых в большей степени сосредоточены вокруг капитала и результатов его использования (извлечение высокой прибыли, достижение сугубо экономической эффективности и т. д.), а в первую очередь крестьянским (фермерским) хозяйствам, уникальные аспекты функционирования которых позволяют им сочетать самые различные виды деятельности, результаты которой представляют ценность и для самих хозяйств, и для сельских жителей.

Обобщая теоретические и эмпирические материалы можно заключить, что инициирование и всесторонняя поддержка многофункциональности деятельности крестьянских (фермерских) хозяйств положительно воздействует на решение насущных проблем, возникающих не только в рамках конкретных аграрных хозяйств, но и в границах окружающих их территорий (района, области, страны). Примечательный факт относительно следствий многофункциональности. Известный экономист-ученый П. Лабартье, изучив влияние данного явления на развитие социального капитала крестьянских (фермерских) хозяйств, утверждает, что интеграция различных функций на уровне отдельной хозяйственной единицы порождает потребность в новых технических знаниях среди фермеров и других участников сельскохозяйственного производства [Labarthe, 2009].

Продолжая его мысль, другие исследователи устанавливают зависимость между продуктивной многофункциональностью и социальным обучением, которое интерпретируется как интерактивное участие различных заинтересованных сторон в управлении конкретной агроэкосистемой [Warner, 2008].
Новые знания появляются из социального партнерства сельскохозяйственных производителей, ученых (в области ряда дисциплин), профессиональных консультантов, должностных лиц государственных учреждений (и других участников аграрного кластера, обладающих соответствующими полномочиями и компетенциями), которое инкубирует инновационные практики, продвигает диверсификацию товарного производства, расширяет спектр экосистемных услуг, направленных на сохранение биоразнообразия, защиту водоразделов, консервацию (ограничение использования) невозобновляемых природных ресурсов. Потенциал местного населения (знания, навыки, общие ценности, особенная культура, уникальные традиции), формальные и неформальные институты, сформировавшиеся сети являются, по сути, причиной региональных различий относительно конкурентоспособности (то есть в определенной мере объясняют достижение различных уровней развития территорий в аналогичных условиях).

Завершая спецификацию перспектив развития фермерства с позиции выделенных и раскрытых пока еще первых компонентов используемого концептуального подхода [многофункциональность деятельности крестьянских (фермерских) хозяйств в границах сельских территорий, ее пространственная локализация и социальная аффилированность], следует отметить, что объективная и четкая идентификация (на базе исследования оценок сельских жителей) тех функций деятельности крестьянских (фермерских) хозяйств, которые действительно общественно востребованы в границах сельских территорий, целесообразна к применению и в ходе прогнозирования эволюции исследуемого объекта, и в процессе определения направлений и механизмов государственной поддержки фермерства на федеральном и региональном уровнях. Идея же многофункциональности в совокупности с еще одним базовым элементом, таким как организационно-технологические особенности функционирования фермерских хозяйств в определенной локальности, составляет в предлагаемой и используемой концепции методологическую основу анализа, моделирования и планирования развития данно- 
го феномена (фермерства) в мобильных условиях среды.

В связи с вышесказанным, определяя основные тенденции и в конечном итоге траектории развития крестьянских (фермерских) хозяйств, прежде всего в областях Уральского федерального округа, примем в расчет, во-первых, благоприятствующие развитию фермерства обстоятельства (местоположение области, ресурсный потенциал, специализация деятельности, применяемые технологии, возможности развития кооперации, наличие государственной поддержки), во-вторых, различные сложности, возникающие в процессе фермерской деятельности (диспаритет цен на аграрную продукцию и используемые в ее производстве активы, высокие производственные и трансакционные издержки на осуществление сельскохозяйственной деятельности, неблагоприятная сельская демография и др.).

Немаловажное значение при этом имеет общее состояние аграрной отрасли экономики в регионе, в ходе исследования которого можно отметить множество положительных тенденций, наблюдаемых в последние годы практически во всех сферах деятельности фермеров (в животноводстве, растениеводстве, овощеводстве и др.).

В первую очередь обратим внимание на то, что основой жизнеспособности крестьянских (фермерских) хозяйств (как функционирующих на протяжении многих лет, так и вновь созданных) является, как показывает опыт фермерской деятельности, их рациональная специализация. При этом выбор направления деятельности каждого крестьянского (фермерского) хозяйства представляет собой, с одной стороны, важное индивидуальное решение его главы, основанное на глубоком сопоставлении возможностей использования имеющихся ресурсов и ожидаемых результатов, с другой - общественную перспективу развития фермерства в регионе.

Учитывая сложившиеся в настоящее время условия, большая часть глав крестьянских (фермерских) хозяйств УФО (особенно это касается территорий Южного Урала и Зауралья) отказывается от разведения животных в производственных масштабах, концентрируясь (в основном) на возделывании либо зерновых культур, либо овощных. Такое решение объясняется тем, что в растениеводстве складывается более адекватная по сравнению с животноводством ценовая политика, имеется больше возможностей как для формирования материально-технической базы, так и для внедрения новых технологий. Что же касается животноводства, то фермерам, как правило, достаточно сложно вести хозяйство в охватываемых отраслью сферах деятельности по самым различным объективным причинам, в частности, из-за высокой трудоемкости технологических операций, неприемлемой для небольших предприятий капиталоемкости производства, сложностей с реализацией продукции, низкой общей рентабельности. Тем не менее следует констатировать, что некоторые фермеры Южного Урала и Зауралья специализируются, благодаря государственным программам поддержки крестьянских (фермерских) хозяйств, на птицеводстве, свиноводстве (основанных на собственной кормовой базе) и даже нацелены (как показал опрос) на разведение скота молочных и специализированных мясных пород. В целом мясное скотоводство (а следовательно получение говядины высокого качества) - перспективная для областей Урала отрасль, развитие которой обеспечено наличием необходимых ресурсов. Например, целесообразно: 1) использовать естественные кормовые угодья территории, повышая для этого продуктивность природных сенокосов и пастбищ; 2) строить специализированные помещения для скота, пользуясь всеми современными возможностями (инновационные технологии, новейшее оборудование, государственная поддержка). Немаловажный факт. Как показывают практика и результаты многочисленных исследований, разумное сочетание в хозяйственной деятельности растениеводческого и животноводческого производства (на основе его диверсификации) в обстановке высокой неопределенности является условием как предупреждения рисков (природных и рыночных), так и эффективной утилизации факторов производства. В региональном масштабе (что касается УФО, к примеру) такая интеграция детерминирует, во-первых, оптимальное использование всех имеющихся в областях ресурсов, во-вторых, обеспечение продовольствен- 
ной безопасности региона [Prospects of the Farming Sector ..., 2014].

И все же сегодняшняя статистика демонстрирует невысокий фермерский вклад в растениеводческое и животноводческое производство в областях УФО (Челябинской, Тюменской, Свердловской, Курганской). При этом деятельность крестьянских (фермерских) хозяйств в каждой из областей дифференцируется, фокусируясь, помимо основного производства, на таких видах активности, как: 1) частичная переработка сельскохозяйственного сырья; 2) операции по реализации продукции; 3) оказание сельскому населению различного вида услуг (строительство и ремонт домов, вспомогательные работы на садовых участках и в огородах). В связи с последней особенностью в хозяйственной лексике становится популярной дефиниция «опорный фермер», означающая, что у селян появляются возможности рассчитывать в их хозяйственной и повседневной жизни на помощь глав местных фермерских хозяйств.

Сопоставляя статистические данные за годы рыночных реформ, можно заключить, что динамика развития фермерского производства в Российской Федерации и областях УФО испытывает определенные флуктуации, но отражает все же явно положительный тренд в основных подотраслях сельского хозяйства [Регионы России ..., 2019].

Так, объемы производства зерна в фермерских хозяйствах увеличиваются с 2005 г. по 2018 г. в среднем в 2,3-2,4 раза [в Челябинской области - в 3 раза, в Курганской области - в 2,7 раза, несколько меньше (в 1,5 раза) - в Свердловской и Тюменской областях]. За этот же период в крестьянских (фермерских) хозяйствах анализируемых субъектов производство мяса (скот и птица на убой) возрастает примерно в 2,7 раза, молока - в 2,5 раза [Регионы России ... , 2019, с. 642-649].

В результате оценка вклада аграрных хозяйств различных организационных форм наглядно демонстрирует, что структура производства сельскохозяйственной продукции в Российской Федерации в течение последних лет перманентно (хотя и медленно) меняется в пользу крестьянских (фермерских) хозяйств, при этом сельскохозяйственные организации постепенно восстанавливают свои утраченные позиции, а доля хозяйств населения постоянно сокращается [Регионы России ... , 2019, с. 716-737; Сельское хозяйство ..., 2019, c. 20-21]. К примеру, за период с 2000 г. по 2018 г. доля хозяйств населения в структуре продукции сельского хозяйства сокращается с 51,6 \% до $31 \%$, доля сельскохозяйственных организаций увеличивается с 45,2 \% до $56,5 \%$, а доля крестьянских (фермерских) хозяйств возрастает с 3,2 \% до 12,5 \% [Сельское хозяйство ..., 2019, с. 21].

Прогнозируя тренды развития крестьянских (фермерских) хозяйств в областях УФО, можно отметить, что они способны (благодаря определенным преимуществам) занять достойное место в производстве всех основных видов продукции сельского хозяйства (зерно, мясо, молоко) в Уральском регионе.

Определяя дальнейшие перспективы фермерства, напомним, что, несмотря на определенные конкурентные преимущества инвесторо-ориентированных форм аграрного бизнеса (сельскохозяйственных организаций), заключающиеся в наличии широких возможностей привлекать капитал и другие факторы производства к его расширению, с одной стороны, и применять новейшие стратегии развития - с другой, современная экономическая наука всесторонне аргументирует необходимость дальнейшего развития индивидуальных крестьянских (фермерских) хозяйств. При этом представители новой институциональной теории обосновывают эту точку зрения:

1) низкими трансакционными издержками данной формы хозяйствования [Wegren et al., 2018];

2) отсутствием рисков возникновения так называемой «проблемы безбилетника» («freeriding problem»), присущей крупным организациям [Networking ..., 2019];

3) высокой мотивацией к эффективной деятельности [Prospects of the Farming Sector ... , 2014].

Более того, материалы научно-теоретических и эмпирических исследований [О фермерстве ..., 2019] доказывают, что современные крестьянские (фермерские) хозяйства УФО имеют неплохие перспективы развития благодаря, прежде всего, долгосрочному планированию, постоянному освоению новых ви- 
дов деятельности, интеграции в смежные ступени технологической цепи, систематическому совершенствованию производственных процессов, имеющимся ресурсам (земля, современный технопарк, инновационные технологии, человеческий капитал и другое), а также определенным личностным качествам и способностям их глав (и членов), которые обеспечивают успешную адаптацию хозяйств к турбулентно меняющейся среде.

Однако, согласно статистике и результатам опроса, далеко не все исследуемые крестьянские (фермерские) хозяйства успешно конкурируют с более крупными аграрными предприятиями [О фермерстве ... , 2019], а некоторые из них, напротив, имеют низкие показатели в производственной и финансово-экономической деятельности вследствие таких объективных причин, как: 1) неурегулированность земельных отношений; 2) недоступность для многих фермеров банковских займов; 3) трудности с реализацией производимой продукции; 4) проблемы с обновлением сельхозтехники, приобретением других необходимых ресурсов.

В условиях сложившихся вызовов и угроз решение всех вышеперечисленных проблем становится предельно важным для успешного функционирования и дальнейшего развития крестьянских (фермерских) хозяйств на территории УФО даже в русле тех положительных трендов, которые формируются для данного типа хозяйственных единиц с учетом многофункциональности их деятельности и важного места в сложившейся региональной специализации.

\section{Выводы}

Проведенное научно-теоретическое и эмпирическое исследование, базирующееся на особой методологии определения перспективных траекторий развития фермерства (многофункциональность, территориальные и технологические особенности), позволяет обозначить ряд важных моментов в функционировании крестьянских (фермерских) хозяйств в областях УФО, а в дальнейшем спрогнозировать возможные тренды их эволюции:

1. Крестьянские (фермерские) хозяйства, будучи специфическими (в том числе по организационным характеристикам) производственными единицами, могут выполнять экономические, социальные и экологические функции (в совокупности), способствуя тем самым устойчивому развитию сельских территорий и сельских сообществ (что особенно востребовано в экстраординарных политических, экономических и других обстоятельствах).

2. Траектории развития крестьянских (фермерских) хозяйств в определенном территориальном пространстве зависят (ввиду их специфической территориальной принадлежности и глубокой встроенности в жизнедеятельность сельских сообществ) от многих уникальных обстоятельств, таких как стартовый уровень развития, имеющиеся региональные возможности (земельные и финансовые ресурсы, техника и технологии, человеческий капитал и др.), особенности формальной и неформальной институциональной среды, сложившейся в границах той или иной локальности.

3. В прогнозировании дальнейшей эволюции фермерства в современных отечественных условиях среды существенное значение имеют не только внутренние и общественно определяемые целевые установки в деятельности фермерских хозяйств (включая многоаспектность), но и организационно-технологические особенности их функционирования на конкретных сельскохозяйственных рынках.

Кроме того, резюмируя полученные теоретические и прикладные результаты исследования можно наметить несколько значимых выводов.

Во-первых, несмотря на слабые (неоднократно отмеченные исследователями) стороны функционирования крестьянского (фермерского) хозяйства, возможности сохранения данной формы организации сельскохозяйственного производства (в соответствии с изложенным концептуальным подходом) все же существуют, а перспективные траектории развития фермерских хозяйств связаны с таким аспектом их деятельности, как многофункциональность (в том числе очевидная социальная направленность), что становится особенно значимым в настоящее время с учетом возникающих вызовов и угроз различного характера. В таких условиях 
российское фермерство получает признание (как это продемонстрировали эмпирические исследования в отдельных областях УФО) не только исходя из важности выполняемых им экономических задач, но и с точки зрения его широких возможностей в решении выходящих сегодня на первый план социальных и экологических проблем.

Во-вторых, пространственная локализация и социальная аффилированность деятельности крестьянских (фермерских) хозяйств означают наличие различий в характеристиках окружающей фермерство среды (институциональной, рыночной), что обусловливает территориальные особенности формирующихся трендов его развития, важность поддержки местными сообществами, необходимость индивидуализации направлений и инструментов государственной поддержки в границах тех или иных регионов.

В-третьих, в определении оптимального (с позиции самих фермеров и общества) вектора развития фермерских хозяйств предельно важное значение имеют эффективная специализация и разумная дифференциация их деятельности, готовность к изменениям, способность адаптироваться к трансформации окружающей среды.

По сути, с точки зрения предложенной в работе концепции развития фермерства, главы фермерских хозяйств находятся сегодня в ситуации выбора: 1) продвигаться по пути традиционного фермерства, развиваясь за счет поиска уникальных ниш в производстве сельскохозяйственной продукции, сохраняя семейные основы фермерского бизнеса, уделяя должное внимание неэкономическим (социальным, экологическим) целям функционирования; 2) сосредоточиться на существенной трансформации своего организационного устройства, ориентируясь на сугубо предпринимательские цели, существенно расширяя деятельность за счет активного привлечения всех видов ресурсов (земля, рабочая сила, финансовые активы), внедряя инвесторо-ориентированные элементы в структуру собственности, управления и организации производства, фокусируясь на индустриальных стратегиях и инновациях (одновременно выполняя социально значимые на селе функции).
Как показывает теория и практика, оба направления имеют право на существование, способствуя сохранению фермерства, его дальнейшему успешному развитию.

\section{ПРИМЕЧАНИЕ}

${ }^{1}$ Исследование выполнено при финансовой поддержке РФФИ и Челябинской области в рамках научного проекта № 20-410-740018.

The research was funded by RFBR and Chelyabinsk Region, project number 20-410-740018.

\section{СПИСОК ЛИТЕРАТУРЫ}

Гайсин, Р. С. Эволюция технологических укладов в аграрной сфере экономики: (записки к юбилею Тимирязевской академии) / Р. С. Гайсин // Journal of Corporate Management and Economics «Maneco». - 2016. - № 7. - C. 13-24.

Головина, С. Г. Многофункциональное сельское хозяйство - основа конкурентоспособности региона / С. Г. Головина, С. В. Пугин // Вестник Курганской ГСХА. - 2016. - № 2 (18). C. 19-23.

Кравченко, Т. С. Потенциал экономического роста крестьянских (фермерских) хозяйств: региональный аспект / Т. С. Кравченко, Н. А. Сухочева // Экономика сельского хозяйства России. - 2018. - № 2. - С. 30-36.

О фермерстве и кооперации / С. Г. Головина [и др.]. Екатеринбург : Изд-во Уральского ГАУ, 2019. $296 \mathrm{c}$.

Поддержка фермерства и кооперации. Сайт Департамента АПК Курганской области. 2020. Электрон. текстовые дан. - Режим доступа: http://dsh.kurganobl.ru/6584. - Загл. с экрана.

Путин, В. В. Приветственная телеграмма в адрес делегатов и участников XXVIII Съезда АККОР. 25.01.2018 / В. В. Путин. - Электрон. текстовые дан. - Режим доступа: https://www.akkor. ru/kommentariy/4617-v.html. - Загл. с экрана.

Путин, В. В. Приветственная телеграмма в адрес делегатов и участников XXXI Съезда АККОР. 19.02.2020 / В. В. Путин. - Электрон. текстовые дан. - Режим доступа: https://www.akkor. ru/statya/6911-v-moskve-prohodit-xxxi-sezdakkor.html. - Загл. с экрана.

Региональный проект «Создание системы поддержки фермеров и развитие сельской кооперации в Челябинской области». 2020. Электрон. текстовые дан. - Режим доступа: http://www. chelagro.ru/national-project/regproekt-sistemapodd-fermer-razv-koop.php. - Загл. с экрана. 
Регионы России. Социально-экономические показатели. 2019 : стат. сб. - М. : Росстат, 2019. $1204 \mathrm{c}$.

Сельское хозяйство в России : стат. сб. - М. : Росстат, 2019. - $91 \mathrm{c}$.

Cairol, D. Multifunctionality of Agriculture and Rural Areas as Reflected in Policies: The Importance and Relevance of the Territorial View / D. Cairol // Journal of Environmental Policy and Planning. 2009. - Vol. 11, № 4. - P. 269-289. - DOI: https:// doi.org/10.1080/15239080903033846.

Easley, R. F. Capturing Group Preferences in a Multicriteria Decision/ R. F. Easley, J. S. Valacich, M. A. Venkataramanan // European Journal of Operational Research. - 2000. - Vol. 125, № 1. P. 73-83. - DOI: https://doi.org/10.1016/S03772217(99)00196-4.

Kallas, Z. Decomposing the Value of Agricultural Multifunctionality: Combining Contingent Valuation and the Analytical Hierarchy Process / Z. Kallas, A. Gomez-Limon, J. B. Hule // Journal of Agricultural Economics. - 2007. - Vol. 58, № 2.P. 218-241. - DOI: https://doi,org/10.1111/j.14779552.2007.00085.x.

Knickel, K. A Critical Reflection of the Meaning of Agricultural Modernization in a World of Increasing Demands and Finite Resources / K. Knickel, R. Zemeckis, T. Tisenkopfs // Proceedings of the International Scientific Conference «Rural Development 2013». - 2013. - Vol. 6, Book 1. P. 561-567. - DOI: https://doi.org/10.13140/ 2.1.4445.7760.

Knickel, R. Methodological and Conceptual Issues in the Study of Multifunctionality and Rural Development/ R. Knickel, H. Renting // Sociologia Ruralis. - 2000. - Vol. 40, №4. - P. 512-528. -DOI: https://doi.org/10.1111/1467-9523.00164.

Labarthe, P. Extension Services and Multifunctional Agriculture. Lessons Learnt from the French and Dutch Contexts and Approaches / P. Labarthe // Journal of Environmental Management. - 2009. - Vol. 90, № 2. - P. 193-202. - DOI: https://doi.org/10. 1016/j.jenvman.2008.11.021.

Networking Among Russian Farmers and Their Prospects for Success / S. Golovina [et al.] // PostCommunist Economies. - 2019. - Vol. 31 (4). P. 484-499. - DOI: https://doi.org/10.1080/ 14631377.2018.1537737.

Prospects of the Farming Sector and Rural Development in View of Food Security: The Case of the Russian Federation / V. Uzun [et al.]. Luxembourg : [s. 1.], 2014.-138 p.

Saaty, T. L. The Analytic Hierarchy Process: Planning, Priority Setting, Resource Allocation / T. L. Saaty. N.Y. :McGraw-Hill, 1980.-287p.
Unay, G. I. The Impact of Green Economy Measures on Rural Employment: Green Jobsin Farms / G. I. Unay, S. Bojnec // Journal of Cleaner Production. 2019. - № 208. - P. 541-551. -DOI: https://doi.org/ 10.1016/j.jclepro.2018.10.160.

Warner, K. D. From «Weak» to «Strong» Multifunctionality: Conceptualising Farm-Level Multifunctional Transitional Pathways / K. D. Warner // Journal of Rural Studies. - 2008. - Vol. 24, № 3. - P. 367-383. DOI: https://doi.org/10.1016/j.jrurstud.2007.12.010.

Wegren, S. Introduction to Symposium: Smallholders in Communist and Postcommunist Societies / S. Wegren, D. O'Brien // Journal of Agrarian Change. - 2018. - Vol. 18 (4). - P. 869-881. DOI: https://doi.org/10.1111/joac.12281.

\section{REFERENCES}

Gaysin R.S. Evolyutsiya tekhnologicheskikh ukladov v agrarnoy sfere ekonomiki: (zapiski k yubileyu Timiryazevskoy akademii) [Evolution of Technological Structures in the Agrarian Sphere of the Economy: (Notes for the Anniversary of the Timiryazev Academy)]. Journal of Corporate Management and Economics "Maneco", 2016, no. 7, pp. 13-24.

Golovina S.G., Pugin S.V. Mnogofunktsional'noe sel'skoe khozyaistvo - osnova konkurentosposobnosti regiona [Multifunctional Agriculture Is the Basis of the Region's Competitiveness]. Vestnik Kurganskoi GSKhA. [Bulletin of the Kurgan State Agricultural Academy], 2016, no. 2(18), pp. 19-23.

Kravchenko T.S., Suhocheva N.A. Potencial ekonomicheskogo rosta krest'yanskih (fermerskih) hozyajstv: regional'nyj aspekt [Potential of Economic Growth of Peasant (Farmer) Households: Regional Aspect]. Ekonomika sel'skogo hozyajstva Rossii [Russian Agricultural Economics], 2018, no. 2,pp. 30-36.

Golovina S.G., Myl'nikov E.A., Smirnova L.N., LoretcE.E. $O$ fermerstve $i$ kooperacii [Farming and Cooperation]. Yekaterinburg, Izd-vo Uralskogo GAU, 2019, p. 296.

Podderzhka fermerstva $i$ kooperacii. Sajt Departamenta APK Kurganskoj oblasti [Support for Farming and Cooperation. Website of the Department of Agriculture of Kurgan Region]. 2020. URL: http://dsh.kurganobl. $\mathrm{ru} / 6584$.

Putin V.V. Privetstvennaya telegramma $v$ adres delegatov i uchastnikov XXVIII Syezda AKKOR [Welcoming Telegram Addressed to Delegates and Participants of the XXVIII Congress of AKKOR]. January 25, 2018. URL: https:// www.akkor.ru/kommentariy/4617-v.html. 


\section{УПРАВЛЕНИЕ ЭКОНОМИЧЕСКИМ РАЗВИТИЕМ}

Putin V.V. Privetstvennaya telegramma $v$ adres delegatov i uchastnikov XXXI Syezda AKKOR [Welcoming Telegram Addressed to Delegates and Participants of the XXXI Congress of AKKOR]. February 19, 2020. URL: https:// www.akkor.ru/statya/6911-v-moskve-prohoditXXXI -sezd-akkor.html.

Regional'nyj proekt «Sozdanie sistemy podderzhki fermerov $i$ razvitie sel'skoj kooperacii $v$ Chelyabinskoj oblasti» [Regional Project "Creation of a Support System for Farmers and the Development of Rural Cooperation in the Chelyabinsk Region"]. 2020. URL: http:// www.chelagro.ru/national-project/regproektsistema-podd-fermer-razv-koop.php.

Regiony Rossii. Sotsial'no-ekonomicheskie pokazateli. 2019: stat. sb. [Regions of Russia. Socioeconomic indicators. 2019. Statistical Compilation]. Moscow, Rosstat, 2019. 1204 p.

Sel'skoe hozyajstvo v Rossii: stat. sb. [Agriculture in Russia. Statistical Compilation]. Moscow, Rosstat Publ., 2019.91 p.

Cairol D. Multifunctionality of Agriculture and Rural Areas as Reflected in Policies: The Importance and Relevance of the Territorial View. Journal of Environmental Policy and Planning, 2009, vol. 11, no. 4, pp. 269-289. DOI: https://doi.org/ 10.1080/15239080903033846.

Easley R.F., Valacich J.S., Venkataramanan M.A. Capturing Group Preferences in a Multicriteria Decision European. Journal of Operational Research, 2000, vol. 125, no. 1, pp. 73-83. DOI: https://doi.org/10.1016/S0377-2217(99)00196-4.

Kallas Z., Gomez-Limon A., Hule J.B. Decomposing the Value of Agricultural Multifunctionality: Combining Contingent Valuation and the Analytical Hierarchy Process. Journal of Agricultural Economics, 2007, vol. 58, no. 2, pp. 218-241. DOI: https://doi.org/10.1111/j.14779552.2007.00085.x.

Knickel K., Zemeckis R., Tisenkopfs T. A Critical Reflection of the Meaning of Agricultural Modernization in a World of Increasing Demands and Finite Resources. Proceedings of the International Scientific Conference «Rural Development 2013», 2013, vol. 6, book 1, pp. 561-567. DOI: https://doi.org/10.13140/ 2.1.4445.7760.

Knickel R., Renting H. Methodological and Conceptual Issues in the Study of Multifunctionality and Rural Development. Sociologia Ruralis, 2000, vol. 40, no. 4,pp. 512-528. DOI: https://doi.org/ 10.1111/1467-9523.00164.

Labarthe P. Extension Services and Multifunctional Agriculture. Lessons Learnt from the French and Dutch Contexts and Approaches. Journal of Environmental Management, 2009, vol. 90, no. 2, pp. 193-202. DOI: https://doi.org/10.1016/ j.jenvman. 2008.11.021.

Golovina S., Hess S., Nilsson J., Wolz A. Networking Among Russian Farmers and Their Prospects for Success. Post-Communist Economies, 2019, vol. 31 (4), pp. 484-499. DOI: https://doi.org/ 10.1080/14631377.2018.1537737.

Uzun V., Saraikin V., Gataulina E., Shagaida N., Yanbykh R., Mary S., Gomez y Paloma S. Prospects of the Farming Sector and Rural Development in View of Food Security: The Case of the Russian Federation. Luxembourg, [s.n.], 2014. 138 c.

Saaty T.L. The Analytic Hierarchy Process: Planning, Priority Setting, Resource Allocation. New York, McGraw-Hill, 1980. 287 p.

Unay G.I., Bojnec S. The Impact of Green Economy Measures on Rural Employment: Green Jobs in Farms. Journal of Cleaner Production, 2019, no. 208, pp. 541-551. DOI: https://doi.org/ 10.1016/j.jclepro. 2018.10.160.

Warner K.D. From "Weak" to "Strong" Multifunctionality: Conceptualising Farm-Level Multifunctional Transitional Pathways. Journal of Rural Studies, 2008, vol. 24, no. 3, pp. 367383. DOI: https://doi.org/10.1016/ j.jrurstud.2007.12.010.

Wegren S., O'Brien D. Introduction to Symposium: Smallholders in Communist and Postcommunist Societies. Journal of Agrarian Change, 2018, vol. 18 (4), pp. 869-881. DOI: https://doi.org/ $10.1111 /$ joac. 12281 . 


\section{Information About the Authors}

Svetlana G. Golovina, Doctor of Sciences (Economics), Professor, Chief Researcher, Research Institute of Agrarian and Environmental Problems and Agricultural Management, Ural State Agrarian University, Karl Libknekht St, 42, 620075 Yekaterinburg, Russian Federation, s_golovina@yahoo.com, https://orcid.org/0000-0002-1157-8487

Ekaterina V. Abilova, Candidate of Sciences (Economics), Associate Professor, Department of Management, Faculty of Management, Chelyabinsk State University, Bratyev Kashirinykh St, 129, 454001 Chelyabinsk, Russian Federation, ekaterina.abilova@mail.ru, https://orcid.org/0000-0003-0186-192 1

\section{Информация об авторах}

Светлана Георгиевна Головина, доктор экономических наук, профессор, главный научный сотрудник Научно-исследовательского института аграрно-экологических проблем и управления сельским хозяйством, Уральский государственный аграрный университет, ул. Карла Либкнехта, 42, 620075 г. Екатеринбург, Российская Федерация, s_golovina@yahoo.com, https://orcid.org/0000-0002-1157-8487

Екатерина Викторовна Абилова, кандидат экономических наук, доцент кафедры менеджмента факультета управления, Челябинский государственный университет, ул. Братьев Кашириных, 129, 454001 г. Челябинск, Российская Федерация, ekaterina.abilova@mail.ru, https://orcid.org/0000-0003-0186-1921 